IZA DP No. 9804

The Impact of Television Programmes on Teenage Career Aspirations: The 'MasterChef Effect'

Giorgio Di Pietro

March 2016 


\title{
The Impact of Television Programmes on Teenage Career Aspirations: The 'MasterChef Effect'
}

\author{
Giorgio Di Pietro \\ Westminster Business School \\ and IZA
Discussion Paper No. 9804
March 2016

\author{
IZA \\ P.O. Box 7240 \\ 53072 Bonn \\ Germany \\ Phone: +49-228-3894-0 \\ Fax: +49-228-3894-180 \\ E-mail: iza@iza.org
}

Any opinions expressed here are those of the author(s) and not those of IZA. Research published in this series may include views on policy, but the institute itself takes no institutional policy positions. The IZA research network is committed to the IZA Guiding Principles of Research Integrity.

The Institute for the Study of Labor (IZA) in Bonn is a local and virtual international research center and a place of communication between science, politics and business. IZA is an independent nonprofit organization supported by Deutsche Post Foundation. The center is associated with the University of Bonn and offers a stimulating research environment through its international network, workshops and conferences, data service, project support, research visits and doctoral program. IZA engages in (i) original and internationally competitive research in all fields of labor economics, (ii) development of policy concepts, and (iii) dissemination of research results and concepts to the interested public.

IZA Discussion Papers often represent preliminary work and are circulated to encourage discussion. Citation of such a paper should account for its provisional character. A revised version may be available directly from the author. 


\section{ABSTRACT \\ The Impact of Television Programmes on Teenage Career Aspirations: The 'MasterChef Effect'}

In recent years, in Italy, a larger number of students have chosen to attend vocational hospitality and catering schools. This paper investigates the extent to which this increase may have been triggered by the growing popularity of the cooking reality show MasterChef, in which the chef profession is portrayed as exciting and glamorous. Using panel data methods and controlling for several potential confounding variables, the analysis attempts to separate the effect of MasterChef from that of other determinants of the decision to attend vocational hospitality and catering schools. The results show that an increase of one percentage point in the audience of MasterChef is associated with an increase in the proportion of final year lower secondary school students willing to enrol at vocational hospitality and catering schools of between 0.25 and 0.35 percentage points. This finding suggests that popular television programmes like MasterChef may play an important role in complementing and supplementing government measures aimed at promoting vocational training among youths.

JEL Classification: $\quad$ I21, J44, C23

Keywords: teenage career aspirations, vocational hospitality and catering schools, panel data analysis, MasterChef

Corresponding author:

Giorgio Di Pietro

University of Westminster

Westminster Business School

Department of Economics and Quantitative Methods

35 Marylebone Road

NW1 5LS London

United Kingdom

E-mail: G.D.I.Pietro@westminster.ac.uk 


\section{Introduction}

There is a broad consensus in the literature about the crucial role played by television in shaping beliefs, attitudes and values of young people. Adolescents typically turn to television for entertainment but acquire a considerable amount of information from what they watch (Huston et al., 1997; Valkenburg, 2004). In particular, it has been shown that television is an important source of occupational information for teenagers and has the potential to introduce them to careers they may not have been previously considered (Hoffner et al., 2006). Jobs or careers of television characters may appeal to youths and serve as role models in the development of their occupational aspirations.

Two main theories have been proposed to explain the mechanism through which the television exerts an influence on the way young people develop work-related values and occupational aspirations: cultivation theory and wishful identification. These mechanisms should be thought of as complementary rather than competing. Cultivation theory (Gerbner et al., 1980) asserts that heavy viewers of TV tend to believe that the world portrayed by television represents an accurate depiction of the real world. Some jobs, though, may appear on television to be more exciting and glamorous than they are in reality. Wishful identification is a psychological process through which a person desires or attempts to become like another person such as a media character (Feilitzen and Linne, 1975; Hoffner, 1996). Young viewers may identify with television characters whom they perceive to be attractive, successful, and admired by others. They may vicariously participate in the characters’ experiences during a programme (Cohen, 2001).

Though there are many studies asserting that teenagers' educational choices and occupational aspirations are influenced by television role models, a limitation of these studies is that the evidence supporting this claim is suggestive but not compelling. 
Some studies report only anecdotal evidence. For instance, Paton (2013) argues that Manchester University has been forced to increase entry requirements for its physics course significantly following a surge in applications driven by the growing popularity of Professor Brian Cox, one of the department's academics and presenter of television series such as Stargazing Live and Wonders of the Universe.

Other studies make general statements without any facts or scientific analysis to back them up. Dunphy (2008) suggests that the popularity of James Bond books and movies has led many people to apply for employment with the British Secret Intelligence Services (MI-6) in hopes of finding a career promising adventure and fame.

Several studies attribute the considerable increase in applications and enrolment experienced by US degree programmes in forensic science since 2000 to the release of the television series Crime Scene Investigation (CSI) and its various spin-off and copies. At West Virginia University, the forensic and investigative sciences programme has grown from 4 graduates in 2000 to more than 500 students in 2006 (Houck, 2006). Michigan State University’s forensic science graduate programme has seen the number of applicants more than doubling, going from 60 applicants in its inaugural year (1994) to 147 less than ten years later (Smallwood, 2002). There is additional evidence from other countries suggesting that the viewing of forensic science television shows has inspired many students to pursue a forensic-related degree. In the UK, the number of degree courses in forensic science has rocketed, from just 2 in 1990 to 285 in 2009 (Dowling, 2009). However, as noted by McManus (2008), these studies are unable to identify whether the CSI effect is the actual cause of increased youth interest in forensics or if the increased interest was driven by other factors that coincided with the development of the CSI effect, such as increased use of forensic science in trials. 
Similarly, Torry (1996) suggests that there may be a link between the increase in applications received by US law schools in the late 1980s and the great success of L.A. Law, a TV series that glamorized the legal profession and ran between 1986 and 1994. Nevertheless, it is unclear whether the drop in the number of applications to law schools observed at the beginning of the 1990s is due to the cancellation of the series or worsening labour market prospects for young lawyers.

There are also several survey-based studies where students were asked to indicate the main factors that had driven their educational choice, including the influence exerted by television. Not only are these studies unable to determine the influence of a specific television programme, but they often rely on relatively small samples of students, and hence it is difficult to generalize their results. For example, Soria et al. (2006), using data on 105 second-year university students from the Faculty of Medicine of the University of Zaragoza (Spain), find that 11 percent of them believed that their decision to study medicine was influenced by television. Larsen et al. (2003) analyse the factors influencing the decision to become a nurse. 495 students from three types of programmes in North Carolina were asked to complete a survey during the first month of their nursing studies. Approximately 22 percent of the sample reported that their decision to become a nurse was affected by television and media.

This paper adds to the above literature by looking at whether the growing popularity of the cooking reality show MasterChef in Italy has led to an increase in the number of students willing to study for a vocational qualification in hospitality and catering. In Italy, as in many other countries, studying hospitality and catering is the starting point for those young people wishing to make cooking their profession. Unlike previous studies, this paper attempts to separate the effect of watching television from the effect of other factors influencing the decision to study for a vocational qualification in hospitality and catering. In addition to 
controlling for several potential confounding variables, the use of panel data analysis (i.e. data are pooled across regions and years) permits the inclusion of region fixed effects and general year effects. These account for time-varying determinants of the decision to attend hospitality and catering schools that are national in scope, as well as for factors that differ across regions but remain constant over years. Region-specific time trends are also added to the model in an attempt to account for confounding factors that vary within regions. In doing so, not only is the potential for omitted variable bias reduced (Ruhm, 2007), but it is also possible to account for all the systematic determinants of enrolment in hospitality and catering courses that are spuriously correlated with the release of MasterChef. Furthermore, in contrast to a lot of previous studies focusing on students studying at a given institution or coming from a specific area (see earlier references), this paper is based on a much more representative sample as it relies on data covering 18 Italian regions out of 20. This gives a more complete picture of the influence exerted by television on the occupational aspirations of young people as the results of this study are likely to be more generalizable. Finally, one should note that data used in this study were not collected at a single time period, but the analysis spans over a 4-year period, thereby considering 4 different seasons of MasterChef.

This paper provides results that are statistically significant and economically meaningful. A one percentage point increase in the proportion of people watching MasterChef is associated with an increase in the share of final year lower secondary school students willing to study at hospitality and catering schools of between 0.25 and 0.35 percentage points. For illustrative purposes, this would imply that if in 2015 an extra 19,005 people were watching MasterChef, the number of students applying for a place at hospitality and catering schools would be expected to increase by a figure between 116 and 162 .

The remainder of this paper is organised as follows. Section 2 provides a brief description of MasterChef and summaries the results of the existing research on the effects of this cooking 
television show on people's eating and consumption habits. Section 3 illustrates the upper secondary education system in Italy and explains what is the best educational path for young people willing to become chefs. Section 4 reports the methodology used in this paper to estimate the influence of MasterChef on students’ decision to attend hospitality and catering schools. Data sources are also described in this Section. Section 5 presents and discusses the empirical results. Section 6 concludes.

\section{MasterChef and the 'MasterChef effect'}

MasterChef is a television reality show where amateur cooks compete for the title of MasterChef. In the series, participants have to pass several stages where they have to prepare tasty dishes in an attempt to impress judges. Contestants love cooking and often are able to transmit their passion to the viewers. Judges are celebrity chefs and leading international food entrepreneurs who mentor and motivate amateur cooks. The winner gets a money prize and publishes his/her own cookbook. This programme offers to both participants and the audience a view of the food industry where the prospect of a culinary career emerges as an attractive option while the negative aspects of it (e.g. long working hours, a lot of physical work involved) appear to be overlooked (Kirkwood and Phillipov, 2015).

The original series of MasterChef began in 1990 on BBC television, UK. The format was first revamped in 2005 and again in 2009. This version of the show has had a tremendous success worldwide and it is currently produced in more than 40 countries. In Italy, the first season of MasterChef was shown primetime every week on Cielo ${ }^{1}$ from September to December 2011. After the success of the first season, three more seasons were made between 2012 and 2015². They were aired primetime every week on Sky Uno³. As shown in Figure 1,

\footnotetext{
${ }^{1}$ Cielo is a free-to-air television channel that was launched on 16 December 2009.

2 The second season was shown between December 2012 and February 2013, the third season between December 2013 and March 2014 and the fourth season between December 2014 and March 2015.
} 
with each new season, the number of people viewing MasterChef during an average minute ${ }^{4}$ has significantly increased ${ }^{5}$.

\section{Insert Figure 1 about here}

The term 'MasterChef effect' has become recognized as jargon that refers to the impact of this show on its viewers. Various pieces of evidence indicate that MasterChef has impacted on the shopping, cooking and eating habits of Australians. A study conducted by IBISWorld shows that Coles Supermarkets, which is a major sponsor of MasterChef Australia, has experienced a dramatic increase in sales of ingredients featured in the series. For instance, the sale of pink ling fish raised by more than 1400 percent the week after it was used on MasterChef and was then advertised in a Coles-promoted recipe (Miletic, 2010). Research has concluded that 6 in every 10 viewers have made at least one dish featured on MasterChef (Passport, 2012). There is also recent evidence that this show has spurred the consumption of wild meat (Gressier, 2016) and dairy spreads (Anderson, 2015).

\section{The Italian upper secondary education: an overview}

The Italian educational system is divided into four cycles: pre-primary school, first educational cycle, second educational cycle and higher education.

Pre-primary school comprises two levels: kindergarten (for children from 0 to 3 years old) and nursery school (for children from 3 to 5 years old). However, children do not have to attend kindergarten or nursery school.

\footnotetext{
${ }^{3}$ Sky Uno is the main channel of the pay-tv Sky Italia. The number of Sky Italia subscribers has risen steadily over the past years. In April 2015 there were about 4.76 million Sky Italia subscribers.

4 The number of viewers of a television programme during an average minute (i.e. average minute rating or AMR) is a well-known audience measure.

5 Though cooking shows have long been a feature of Italian television programming, MasterChef is different in several aspects. First, historically these shows have tended to display chefs showing how to create fabulous meals. Second, several of these cooking shows are aired at lunch time when students are typically at school. Third, MasterChef is by far the most popular one attracting millions of viewers (see Figure 1).
} 
The first educational cycle is compulsory and includes primary and lower secondary education. This cycle takes 8 years: 5 years of primary education and 3 years of lower secondary school.

The second educational cycle is made up of the upper secondary school. On completion of lower secondary education, students, who are aged approximately 14, must choose the upper secondary school they want to attend. There are 3 main types of upper secondary schools: 1 ) Academic-oriented Schools (Licei), which provide academic training to prepare students for tertiary education; 2) Technical Schools (Instituti Tecnici), which are designed to prepare students for technical occupations in the economic and technological fields; and 3) Vocational Schools (Instituti Professionali), which offer vocational training, and where classroom study is combined with practical experience. Each main type is divided into subtypes. Following the entry into force of Gelmini’s reform in September 2010, there are 6 subtypes of Academic-oriented Schools, 11 sub-types of Technical Schools and 6 sub-types of Vocational Schools. The upper secondary school choice is mandatory for all students as school leaving age is 16 . All sub-types of upper secondary schools last for 5 years.

Lower secondary school students are asked to decide which upper secondary school they want to attend about 5 months before completing the first educational cycle. Students can freely choose any school ${ }^{6}$ and, provided there are sufficient places available, they may attend the school of their choice. Since February 2012, students can apply online and select the upper secondary school they want to go to. No information is given about the number of places available or whether the school is typically over or under subscribed. In addition to the preferred school, students can indicate up to two other schools they would like to attend. If a student is not accepted into his/her first school choice, his/her application will be considered

\footnotetext{
${ }^{6}$ There are no admission restrictions for any upper secondary school.
} 
by the other two schools. Admission criteria are set by the governing body of each school. Typically, siblings get priority as well as children living in the catchment area of the school.

The best educational path for students who aspire to become chefs is to attend the sub-type of Vocational schools that is specialised in hospitality and catering (Istituto Professionale Servizi per l'enogastronomia e l'ospitalità alberghiera) ${ }^{7}$. Although no formal qualification is required to become a chef, a vocational qualification in hospitality and catering helps students to gain some of the skills and knowledge needed in the job. Furthermore, hospitality and catering schools tend to have links and collaborations with leading chefs associations and principal figures from the world of gastronomy. Attending hospitality and catering schools is an increasingly popular choice among students in Italy ${ }^{8}$. In 2014 these schools were the second most selected sub-type of upper secondary schools after scientific Academic-oriented schools (Licei Scientifici). In Italy in 2015 there were 262 hospitality and catering schools and they were fairly evenly distributed across regions. In recent years, many of these schools have increased the number of places offered in an attempt to accommodate the higher demand.

Parental advice is one of the most important factors affecting the upper secondary school choice $^{9}$. Given that MasterChef attracts large audiences, one should note that this programme has the capacity to influence teenagers as well as their parents. Therefore, not only may MasterChef encourage young people to pursue a career in food after lower secondary school, but it may also persuade parents that this is a good choice. The increased respectability of the chef profession, resulting from the success of this show, may make parents more open to the

\footnotetext{
${ }^{7}$ In Italy there are no tertiary education programmes in hospitality and catering.

${ }^{8}$ Between the academic years 2011/12 and 2014/15 the percentage of final year lower secondary school students choosing a hospitality and catering school as their preferred upper secondary school out of all final year lower secondary school students increased from 7.54 percent to 8.7 percent.

${ }^{9}$ This is reflected by the fact that in Italy parental characteristics (e.g. parental education and socio-economic status) are found to exert a great impact on the type of upper secondary school attended (Checchi and Flabbi, 2006).
} 
possibility of their children choosing this career path. Alternatively, it is possible that following the viewing of MasterChef parents may even attempt to convince their children to become chefs.

\section{Methodology, data and variables}

This study employs a balanced panel dataset of 18 regions ${ }^{10}$ covering the period from 2011 to $2015^{11}$. Four seasons of MasterChef were broadcasted during this period, i.e. one each year. Timing may play an important role here. Students selected the upper secondary school they wished to attend shortly after the end of MasterChef or when this programme was still being broadcast ${ }^{12}$. This consideration is relevant as it may lead to a stronger influence of MasterChef on students' educational choice. In order to investigate whether the release of MasterChef has affected students' decision to study at hospitality and catering schools, the following model is estimated:

$$
y_{i t}=\beta_{o}+\beta_{1} \text { Masterchefaudience }_{i t}+\beta_{2} Y U N_{i t-1}+\beta_{3}{ }^{\prime} X_{i t-1}+Y_{t}+R_{i}+\varepsilon_{i t} \quad \text { (Eq. 1) }
$$

where the subscript $\mathrm{i}$ indexes regions and the subscript $\mathrm{t}$ indexes years. $y_{i t}$ is the percentage of final year lower secondary school students choosing a hospitality and catering school as their preferred upper secondary school out of all final year lower secondary school students. Masterchefaudience ${ }_{i t}$ denotes the percentage of people watching MasterChef during an average minute out of the total viewing audience ${ }^{13}$. $Y U N_{i t-1}$ refers to youth unemployment rate (the number of unemployed 18-24 year-olds divided by the youth labour

\footnotetext{
${ }^{10}$ Two Italian regions (i.e. Trentino Alto Adige and Valle d'Aosta) are excluded from the analysis as in these regions the process through which students choose the upper secondary school they want to attend is different from that used in the rest of Italy.

${ }^{11}$ There are two reasons why earlier data cannot be used. First, as mentioned in Section 2, MasterChef started in Italy in September 2011. Second, as outlined in Section 3, the release of season 1 of MasterChef coincided with the introduction of an online procedure for applying for a place at upper secondary school.

${ }^{12}$ In 2012 students selected their preferred upper secondary school about one month and half after the end of season 1 of MasterChef. As regards seasons 2, 3 and 4, this decision was taken when MasterChef was still being broadcast (approximately 2 months after the start of the series).

${ }^{13}$ The total viewing audience is made up by individuals aged 4 or over.
} 
force). It is a measure of general labour market prospects for young individuals. $X_{i t-1}$ is a vector comprising 3 different time-variant measures of labour market prospects for chefs and food service professionals. These are:

Percentage of workers in hospitality and catering= workers employed in the hospitality and catering industry out of the total workers.

Percentage of newly founded firms in hospitality and catering= newly founded firms in the hospitality and catering industry out of the total newly founded firms.

\section{Percentage of seasonal workers that firms in hospitality and catering plan to recruit}

during next year $=$ Seasonal workers that firms in the hospitality and catering industry plan to recruit during next year out of the total seasonal workers who are planned to be recruited during next year.

Following the approach of previous studies (see, for instance, Edin and Holmlund, 1993), all the measures of labour market prospects have been lagged one year. In other words, it is hypothesized that students' formation of their expectations of the labour market situation starts one year before they actually enrol.

While $Y_{t}$ is a year-specific effect, $R_{i}$ is a region-specific intercept. The year dummy variables pick up the impact of time-varying omitted determinants that are common across regions. For instance, following the success of MasterChef more food-related programmes have been broadcast by Italian television in recent years. MasterChef junior is, for example, a spin-off of MasterChef and the first Italian version of this series was aired across the entire country in 2014. The region intercepts, often referred to as fixed effects, account for unobserved characteristics that differ across regions but remain constant over time. For instance, historically, Italian regions have different levels of supply of tourism-related services such as 
hotels, restaurants and resorts. This could have led to persistent differences in the demand for vocational education in hospitality and catering across them. $\varepsilon_{i t}$ is the error term with the classical main assumptions ${ }^{14}$.

$\beta_{1}$ is the coefficient of interest and measures the percentage point increase in the percentage of final year lower secondary school students willing to attend hospitality and catering schools attributable to a one percentage point increase in the percentage of people watching MasterChef. It captures the extent to which students have taken inspiration for studying hospitality and catering from MasterChef including the potential influence exerted by their parents also triggered by the viewing of MasterChef (see last paragraph of Section 3)

Nevertheless, one problem with the estimates of Eq. (1) is that they do not account for confounding factors that change over time within regions except to the extent that these are picked up by our parsimonious set of time-variant covariates. In an attempt to address this issue, following the approach of Hinrichs (2012), a vector of region-specific linear time trends $\left(R_{i} * \mathrm{t}\right)$ is added to the model. In light of this, the following model is estimated:

$y_{i t}=\beta_{o}+\beta_{1}$ Masterchefaudience $_{i t}+\beta_{2} Y U N_{i t-1}+\beta_{3}{ }^{\prime} X_{i t-1}+Y_{t}+R_{i}+R_{i} * t+\varepsilon_{i t}$

An important advantage of the panel data method is that it makes use of both the time and cross-section dimensions of the data. Variation across units and over time is used to explain the outcome variable. Additionally, pooling is especially useful in situations where the number of units is modest and the length of the time period is short (Zahariadis, 1997). On the other hand, one disadvantage of our analysis is that aggregate (i.e. regional) data do not contain information on student age, gender and socio-economic background.

${ }^{14} E\left(\varepsilon_{i t}\right)=0 ; E\left(\varepsilon^{2}{ }_{i t}\right)=\sigma^{2}$; and $E\left(\varepsilon_{i}, \varepsilon_{j}\right)=0$, that is mean zero, constant variance and zero covariance. In light of these assumptions, it is well-known that the OLS (Ordinary Least Squares) estimator is the best linear unbiased estimator. 
Data on the number of final year lower secondary school students who have chosen a hospitality and catering school as their preferred upper secondary school come from the Ministry of Education and Research (MIUR). Data on the total number of final year lower secondary school students are also from the MIUR.

The data source for unemployment rate for individuals aged between 18 and 24 is the Italian Institute of National Statistics (ISTAT).

Data on the number of people watching MasterChef during an average minute for seasons 1 to 4 are provided by Sky Italia.

Data on seasonal workers that firms in the hospitality and catering industry plan to recruit during next year out of the total seasonal workers who are planned to be recruited during next year are from the Excelsior database ${ }^{15}$.

Data on the different measures of labour market prospects for chefs and food service professionals are from the Italian Federation of Restaurants, Bars and Hotels (FIPE).

Table 1 provides descriptive statistics for the all variables used in the analysis. It shows that there is sufficient cross sectional variation in the sample to justify the use of panel data techniques. For all the variables except one (i.e. percentage of seasonal workers that firms in hospitality and catering plan to recruit during next year), the standard deviation between regions in the 4 years under examination is higher than that observed within a region over the 4 years.

Insert Table 1 about here

\footnotetext{
${ }^{15}$ The Excelsior database is maintained by Unioncamere Nazionale, which is the Union of the Italian Chambers of Commerce. It can be accessed at http://excelsior.unioncamere.net/xt/geoChooser/scegli-archivio.php (consulted 20 December 2015).
} 


\section{Empirical results}

Before presenting and discussing the estimates of our models, it is important to check for multicollinearity in the explanatory variables. Specifically, one problem regards the possibility that there is a strong correlation between the various measures of labour market prospects included in the models. To address this issue, a test for multicollinearity is performed $^{16}$. The results, which are reported in Table 2, indicate that multicollinearity among variables is not a serious concern in this study. The values of the variable inflation factor (VIF) for the explanatory variables are less than or equal to 1.65 , under the recommended cut point of 2 to rule out problems with multicollinearity (Rabe-Hesketh and Everitt, 2006)

\section{Insert Table 2 about here}

The results for Eq. (1) ${ }^{17}$ are reported in Column 1 of Table 3 . The coefficient on the percentage of seasonal workers that firms in hospitality and catering plan to recruit during next year is positive and statistically significant at 1 percent level. A higher proportion of workers to be employed in this industry provides a great incentive for students to enrol at hospitality and catering schools. The coefficients on the two other measures of labour market prospects for chefs and food service professionals have the expected positive sign and are statistically significant at the 10 percent level. The results suggest also that a higher youth unemployment rate discourages students from choosing to attend catering and hospitality schools. It is possible that the worsening of general labour market conditions may push students to plan to stay longer in education, and hence they may favour academic-oriented schools (those preparing for tertiary education) as opposed to vocational schools. Nevertheless, this effect is not statistically significant.

\section{Insert Table 3 about here}

\footnotetext{
16 The STATA collin command is used.

17 The STATA xtreg, fe command is used.
} 
Moving on to the primary variable of interest of this study, the results provide evidence supporting the proposition that MasterChef influences the upper secondary school choice made by final year lower secondary school students. The coefficient on the percentage of people watching MasterChef is statistically significant and positive, implying that increased viewing of MasterChef is associated with a higher proportion of students willing to study at hospitality and catering schools. Specifically, an increase in the average proportion of people watching MasterChef of 1 percentage point is associated with an increase of 0.292 percentage point in the share of final year lower secondary school students choosing a hospitality and catering school as their preferred upper secondary school.

Though, as outlined in Section 3, there are plausible theoretical arguments for including a full set of year dummies in the model, they are not found to be jointly statistically significant at conventional levels (the result of the F-test is reported at the bottom of Column 1). In light of this, the equation is re-estimated without year dummies in order to preserve degrees of freedom. The new estimates are presented in Column 2 of Table 3. The estimated coefficient on the percentage of people watching MasterChef is still statistically significant at the 5 percent level, though its size becomes smaller than that reported in Column 1. Additionally, the coefficient on youth unemployment rate is now statistically significant.

Estimates of Eq. (2) are shown in Column 3 of Table $3^{18}$. Both the magnitude and the standard error of the coefficient related to MasterChef's audience increase with the inclusion of region-specific trends. However, it is important to note that this coefficient is still positive and statistically significant at conventional levels.

Next, the Hausman test is performed to test whether the fixed effects model is more appropriate than a random effects model (Hausman and Taylor, 1981). The null hypothesis of

\footnotetext{
${ }^{18}$ Year dummies are again excluded from the specification as they are found not jointly statistically significant. The F-statistic value is 0.20 and the corresponding p-value is 0.9 .
} 
this test is that the preferred model is random effects. This implies that region-specific effects are uncorrelated with independent variables included in the model, and hence coefficient estimates from the two models should turn out not to be statistically different. The test statistic, distributed as a $\chi^{2}$ with 22 degrees of freedom (i.e. the number of coefficients in the model), is equal to 50.56 (p-value=0.00). This strongly rejects the null hypothesis that the coefficients are not statistically significant across the two models and therefore indicates a violation of the random-effects assumption. This confirms that the fixed effect model is more appropriate in this analysis.

Despite the suitability of the fixed effect regression model, a number of statistical properties need to be investigated as pooling data across regions and years may generate several estimation issues. To start with, potential cross-sectional dependence (also called contemporaneous correlation) is checked using the Pesaran Cross-Dependence test (CD). This test, which is asymptotically distributed as a standard normal and turns out to be efficient even in panels with small samples where the time dimension is short (Pesaran, 2004), verifies whether residuals are correlated across regions ${ }^{19}$. The result indicates that the null hypothesis of no cross-sectional dependence cannot be rejected ( $p$-value=0.24). Second, the assumption of homoskedasticity may be violated in pooled cross-sectional times series regressions because of the structure of the data. As observed by Stimson (1985), size differences between units (here, regions) may induce heteroskedasticity. To check if heteroskedasticity is present, a modified Wald statistic for groupwise heteroskedasticity in the residuals of the fixed effect regression model is computed (Greene, 2000) ${ }^{20}$. The result of the test indicates that there is variation in the variance of the error terms (groupwise heteroskedasticity) as the null hypothesis can be rejected with a p-value of less than 1

\footnotetext{
19 This test is implemented via the STATA command xtcsd, pesaran abs.

20 This test is implemented via the STATA command xttest3.
} 
percent. Third, in pooled data where the number of cross-sectional units is greater than the number of time periods (i.e. $\mathrm{N}>\mathrm{T}$ ), as is the case in this piece of research, autocorrelation may be present. However, the Wooldridge test for autocorrelation in panel data (Wooldridge, 2002) results in a p-value of 29 percent, failing to reject the null hypothesis and concluding that there is no first-order serial correlation ${ }^{21}$.

Summing up all the results of these diagnostics, it is clear that the fixed effect model reported in Column 3 is heteroskedastic. To deal with this problem, Reed and Ye (2011), given that $\mathrm{N}>\mathrm{T}$, suggest to use Huber-White robust standard errors ${ }^{22}$. This model is therefore re-estimated, but this time Huber-White robust standard errors are computed .These estimates are presented in Column 4 of Table 3. When estimates are corrected for heteroskedasticity, the standard error of the majority of coefficients increases. This, for instance, affects the statistical significance of the parameter on the percentage of seasonal workers that firms in hospitality and catering plan to recruit during next year. However, this pattern does not occur with the coefficient on the percentage of people watching MasterChef given that its standard error slightly decreases (0.184 compared with 0.197$)$.

\footnotetext{
21 This test is implemented in STATA using command xtserial.

${ }^{22}$ An alternative way to deal with the problem of heteroskedasticity is to cluster standard errors at the region level. These estimates are not reported here as they are identical to those shown in Column 4 of Table 3.
} 


\section{Concluding remarks}

Though there are many studies indicating that teenagers' educational choices and occupational aspirations are influenced by television role models, a limitation of this literature is that the evidence supporting this claim is suggestive but not compelling. This paper attempts to fill this gap by offering what appears to be the first systematic quantitative evidence about the effect of television exposure on teenage career aspirations.

The attention is focused here on MasterChef, a cooking reality programme providing the audience with a view of the food industry in which the chef profession emerges as a fulfilling, exciting and challenging career option. In recent years, in Italy, the growing popularity of this show has coincided with an increasing number of students who have chosen to attend vocational hospitality and catering schools. Using panel data methods and controlling for several potential confounding variables, the analysis attempts to disentangle the effect of MasterChef from the effect of other determinants of the decision to attend vocational hospitality and catering schools. The results provide evidence that there is a relationship between MasterChef's audience and youth's increased interest in studying hospitality and catering. Specifically, the estimates indicate that a 1 percentage point increase in the proportion of people watching MasterChef leads to an increase in the share of students willing to study at hospitality and catering schools of between 0.25 and 0.35 percentage points. For illustrative purposes, this would imply that if in 2015 an extra 19,005 people were watching MasterChef, the number of students applying for a place at hospitality and catering schools would be expected to increase between 116 and 162 .

This finding suggests that popular television programmes like MasterChef may play an important role in complementing and supplementing government measures aimed at promoting vocational training among youths. These programmes are a relevant source of 
occupational information for teenagers and may inspire them to pursue a career in subjects covered by vocational education and training. In particular, they may be a vehicle through which the image and the attractiveness of vocational education and training can be improved.

One limitation of this study is the small sample size. Although the data represent almost the entire Italian population (98 percent), the number of observations included in the regressions is small and this makes standard errors regrettable large. Future studies should use more disaggregated data (e.g. city-level) over a longer period of time ${ }^{23}$. ${ }^{23}$ Unfortunately, the present study cannot do this as data at provincial level for MasterChef's audience are
unavailable and, at the time of this paper, only 4 seasons of MasterChef Italy had been released. 


\section{References}

Anderson, E. (2015) Dairy feels 'Masterchef effect. Stock Journal, 5 August. Available at: http://www.stockjournal.com.au/story/3296680/dairy-feels-masterchef-effect （consulted 20 December 2015).

Checchi, D. and Flabbi, L. (2006) Mobilità intergenerazionale e decisioni scolastiche in Italia. In: Ballarino, G. and Checchi, D. (eds.) Sistema scolastico e diseguaglianza sociale, Bologna: ilMulino.

Cohen, J. (2001) Defining identification: A theoretical look at the identification of audiences with media characters. Mass Communication \& Society 4(3): 245-264.

Dowling, T. (2009) The grisly truth behind CSI degrees. The Guardian, 15 October. Available at: http://www.theguardian.com/education/2009/oct/15/csi-effect-forensic-science (consulted 20 December 2015).

Dunphy, P. (2008) James Bond need not apply. Available at: http://commanderbond.net/cw.cgi?action:Story\&SID=2110 (consulted 20 December 2015).

Edin. P.-A. and Holmlund, B. (1993) The Swedish wage structure: The rise and fall of solidarity wage policy? NBER Research Working Paper No 4257.

Feilitzen, C. and Linne, O. (1975) Identifying with television characters. Journal of Communication 25(4):51-55.

Gerbner, G., Gross L., Morgan, M. and Signorelli, N. (1980) The "Mainstreaming" of America: Violence Profile No.11. Journal of Communication 30(3) 10-29. 
Graves, S.B. (1982) The impact of television on the cognitive and affective development of minority children. In Berry GL and Mitchell-Kernan, C (eds) Television and the socialization of the minority child. New York: Academic Press, 37- 67.

Greene, W.H. (2000) Econometric analysis (Fourth Edition). Upper Saddle River, New Jersey: Prentice Hall.

Gressier, C. (2016) Going feral: Wild meat consumption and the uncanny in Melbourne, Australia. The Australian Journal of Anthropology, forthcoming.

Hausman, J.A. and Taylor, W. (1981) Panel data and unobservable individual effects. Econometrica 49(6): 1377-1398.

Hinrichs, P. (2012) The Effects of affirmative action bans on college enrollment, educational attainment, and the demographic composition of universities. The Review of Economics and Statistics 91(4): 712-722.

Hoffner, C.A., Levine, K.J., Sullivan, Q.E., Crowell, D., Pedrick, L. and Berndt, P. (2006) TV characters at work: Television's role in the occupational aspirations of economically disadvantaged youths. Journal of Career Development 33(1): 3-18.

Hoffner, C.A. (1996) Children’s wishful identification and parasocial interaction with favorite television characters. Journal of Broadcasting \& Electronic Media 40(3): 389-402.

Houck, M.M. (2006) CSI: Reality. Scientific American. 295(1): 84-89.

Huston, A.C., Wright, J.C., Fitch, M., Wroblewski, R. and Piemyat, S. (1997) Effects of documentary and fictional television formats on children's acquisition of schemata for unfamiliar occupations. Journal of Applied Developmental Psychology 18(4): 563-585. 
Kirkwood, K. and Phillipov, M. (2015) What Masterchef teaches us about food and the food industry. The Conversation. Available at: http://theconversation.com/what-masterchefteaches-us-about-food-and-the-food-industry-41893 (consulted 20 December 2015).

Larsen, P.D., McGill, J.S. and Palmer, S.J. (2003) Perspectives of Nursing Students in Three Types of Programs. Journal of Nursing Education 42(4): 168-73

McManus, S.E. (2008) Influence of the CSI effect on education and mass media. University of Central Florida, Orlando. Available at: http://anthropology.cos.ucf.edu/main/wpcontent/uploads/2012/08/McManus_Sarah_E_201008_MA.pdf (consulted 20 December 2015).

Miletic, D. (2010) MasterChef cooks up a sales storm. The Sydney Morning Herald, 23 July. Available at: http://www.smh.com.au/entertainment/tv-and-radio/masterchef-cooks-up-asales-storm-20100722-10n0c.html (consulted 20 December 2015).

Passport (2012) Consumer foodservice in Australia. Available at: http://www. euromonitor.com/consumer-foodservice-in-australia/report (accessed 20 December 2015).

Paton, G. (2013) Brian Cox effect' leads to surge in demand for physics, The Telegraph, 11 January. Available at:

http://www.telegraph.co.uk/education/universityeducation/9793822/Brian-Cox-effect-leadsto-surge-in-demand-for-physics.html (consulted 20 December 2015).

Pesaran, M.H. (2004) General diagnostic tests for cross section dependence in panels. Cambridge Working Papers in economics. No. 0435 Faculty of Economics, University of Cambridge. 
Rabe-Hesketh, S. and Everitt, B.S. (2006) A handbook of statistical analyses using Stata (Fourth Edition). Boca Raton, FL: Chapman \& Hall/CRC.

Reed, W.R. and Ye, H. (2011) Which panel data estimator should I use? Applied Economics 43(8): 985-1000.

Ruhm, C.J. (2007) A healthy economy can break your heart. Demography 44(4): 829-848.

Smallwood, S. (2002) As seen on TV. Chronicle of Higher Education, 48(45): A8.

Soria, M., Guerra M., Giménez, I. and Escanero, J.F. (2006) La decision de estudiar medicina: características. Educación Médica 9(2): 91-97.

Stimson, J.A. (1985) Regression in space and time: A statistical essay. American Journal of Political Science, 29(4): 914-947.

Stroman, C.A. (1991) Television's role in the socialization of African American adolescents. Journal of Negro Education 60(3): 314-327.

Torry, S. (1996) The paper chase slows down here and nationally, The Washington Post. 10 June. Available at: $\underline{\text { http://www.washingtonpost.com/wp- }}$ adv/classifieds/careerpost/library/lesslaw.htm (consulted 20 December 2015).

Valkenburg, P.M. (2004) Children's responses to the screen: A media psychological approach. Hillsdale, NJ: Lawrence Erlbaum Associates, Inc.

Wooldridge, J.M. (2002) Econometric analysis of cross section and panel data. Cambridge MA: MIT Press.

Zahariadis, N. (1997) Why State Subsidies? Evidence from European Community countries, 1981-1986. International Studies Quarterly 41(2): 341-354. 
Figure 1: MasterChef's audience in seasons 1 to 4

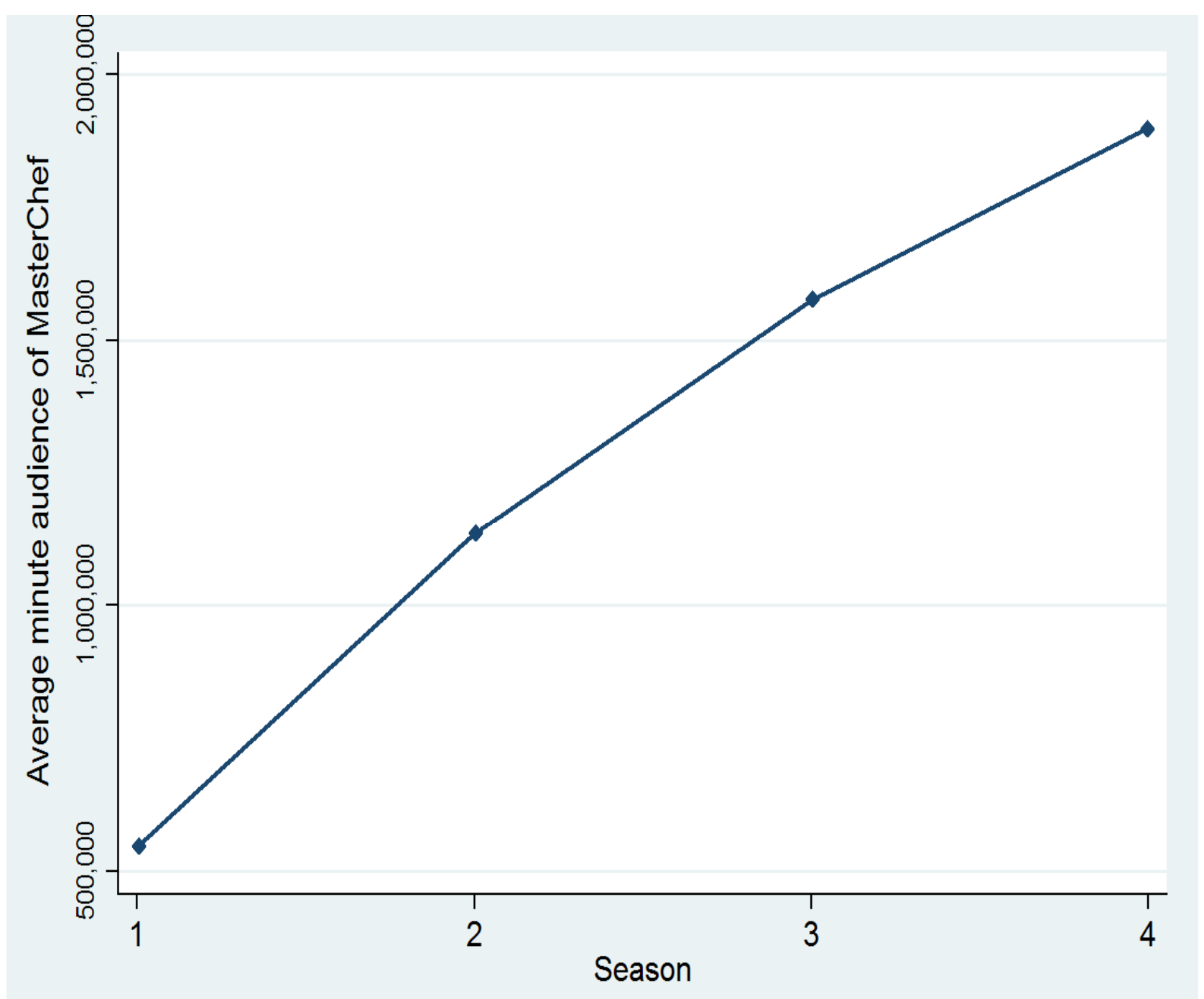


Table 1: Descriptive statistics

\begin{tabular}{|c|c|c|c|}
\hline Variable & & Mean & St. Deviation \\
\hline $\begin{array}{l}\text { Percentage of students } \\
\text { choosing a hospitality and } \\
\text { catering schools as their } \\
\text { preferred upper secondary } \\
\text { school }\end{array}$ & $\begin{array}{l}\text { Overall } \\
\text { Between } \\
\text { Within }\end{array}$ & 0.085 & $\begin{array}{l}0.022 \\
0.021 \\
0.008\end{array}$ \\
\hline $\begin{array}{l}\text { Average percentage of } \\
\text { people watching } \\
\text { MasterChef }\end{array}$ & $\begin{array}{l}\text { Overall } \\
\text { Between } \\
\text { Within }\end{array}$ & 0.021 & $\begin{array}{l}0.016 \\
0.012 \\
0.011\end{array}$ \\
\hline $\begin{array}{l}\text { Percentage of workers in } \\
\text { hospitality and catering }\end{array}$ & $\begin{array}{l}\text { Overall } \\
\text { Between } \\
\text { Within }\end{array}$ & 0.065 & $\begin{array}{l}0.013 \\
0.013 \\
0.003\end{array}$ \\
\hline $\begin{array}{l}\text { Percentage of newly } \\
\text { founded firms in hospitality } \\
\text { and catering }\end{array}$ & $\begin{array}{l}\text { Overall } \\
\text { Between } \\
\text { Within }\end{array}$ & 0.046 & $\begin{array}{l}0.010 \\
0.010 \\
0.004\end{array}$ \\
\hline $\begin{array}{l}\text { Percentage of seasonal } \\
\text { workers that firms in } \\
\text { hospitality and catering } \\
\text { plan to recruit during next } \\
\text { year }\end{array}$ & $\begin{array}{l}\text { Overall } \\
\text { Between } \\
\text { Within }\end{array}$ & 0.072 & $\begin{array}{l}0.027 \\
0.018 \\
0.020\end{array}$ \\
\hline Youth unemployment rate & $\begin{array}{l}\text { Overall } \\
\text { Between } \\
\text { Within }\end{array}$ & 0.383 & $\begin{array}{l}0.110 \\
0.094 \\
0.060\end{array}$ \\
\hline
\end{tabular}

Notes:

$\mathrm{N}$ (number of total observations) $=72$

$\mathrm{N}$ (number of cross-sectional units, i.e. regions) $=18$

$\mathrm{T}$ (number of years, i.e. seasons of MasterChef) $=4$ 
Table 2: Test for multicollinearity

\begin{tabular}{|l|c|c|c|}
\hline Variable & VIF & Tolerance & R-squared \\
\hline $\begin{array}{l}\text { Average percentage of people } \\
\text { watching MasterChef }\end{array}$ & 1.06 & 0.94 & 0.06 \\
\hline $\begin{array}{l}\text { Percentage of workers in hospitality } \\
\text { and catering }\end{array}$ & 1.65 & 0.60 & 0.39 \\
\hline $\begin{array}{l}\text { Percentage of newly founded firms in } \\
\text { hospitality and catering }\end{array}$ & 1.24 & 0.81 & 0.19 \\
\hline $\begin{array}{l}\text { Percentage of seasonal workers that } \\
\text { firms in hospitality and catering plan } \\
\text { to recruit during next year }\end{array}$ & 1.12 & 0.89 & 0.11 \\
\hline Youth unemployment rate & 1.36 & 0.74 & 0.26 \\
\hline
\end{tabular}


Table 3: Panel data estimates of the relationship between MasterChef's audience and willingness to attend hospitality and catering schools among final year lower secondary school students

\begin{tabular}{|c|c|c|c|c|}
\hline & (1) & (2) & (3) & (4) \\
\hline Constant & $\begin{array}{l}-0.004 \\
(0.035)\end{array}$ & $\begin{array}{c}0.022 \\
(0.027)\end{array}$ & $\begin{array}{c}0.030 \\
(0.048)\end{array}$ & $\begin{array}{c}0.030 \\
(0.060)\end{array}$ \\
\hline $\begin{array}{l}\text { Average percentage of people } \\
\text { watching MasterChef }\end{array}$ & $\begin{array}{l}0.292^{* *} \\
(0.137)\end{array}$ & $\begin{array}{l}0.249 * * \\
(0.125)\end{array}$ & $\begin{array}{l}0.354^{*} \\
(0.197) \\
\end{array}$ & $\begin{array}{l}0.354^{*} \\
(0.184)\end{array}$ \\
\hline $\begin{array}{l}\text { Percentage of workers in } \\
\text { hospitality and catering (t-1) }\end{array}$ & $\begin{array}{l}0.968^{*} \\
(0.500)\end{array}$ & $\begin{array}{c}0.756 \\
(0.469)\end{array}$ & $\begin{array}{c}0.246 \\
(0.827)\end{array}$ & $\begin{array}{c}0.246 \\
(0.810)\end{array}$ \\
\hline $\begin{array}{l}\text { Percentage of newly founded } \\
\text { firms in hospitality and catering } \\
(\mathrm{t}-1)\end{array}$ & $\begin{array}{l}0.699 * \\
(0.370)\end{array}$ & $\begin{array}{l}0.617^{*} \\
(0.327)\end{array}$ & $\begin{array}{l}0.934^{*} \\
(0.521)\end{array}$ & $\begin{array}{l}0.934 * \\
(0.684)\end{array}$ \\
\hline $\begin{array}{l}\text { Percentage of seasonal workers } \\
\text { that firms in hospitality and } \\
\text { catering plan to recruit during } \\
\text { next year (t-1) }\end{array}$ & $\begin{array}{c}0.141^{* * *} \\
(0.049)\end{array}$ & $\begin{array}{l}0.136 * * * \\
(0.048)\end{array}$ & $\begin{array}{c}0.138 * * * \\
(0.060)\end{array}$ & $\begin{array}{c}0.169 \\
(0.157)\end{array}$ \\
\hline Youth unemployment rate (t-1) & $\begin{array}{c}-0.065 \\
(0.040) \\
\end{array}$ & $\begin{array}{c}-0.075^{* *} \\
(0.029) \\
\end{array}$ & $\begin{array}{l}-0.041 \\
(0.048)\end{array}$ & $\begin{array}{c}-0.041 \\
(0.075)\end{array}$ \\
\hline \multicolumn{5}{|l|}{ Year dummies-reference is 2011} \\
\hline 2012 & $\begin{array}{c}0.006 \\
(0.007)\end{array}$ & & & \\
\hline 2013 & $\begin{array}{c}0.004 \\
(0.004)\end{array}$ & & & \\
\hline 2014 & $\begin{array}{c}0.005 \\
(0.003)\end{array}$ & & & \\
\hline Region fixed effect & Yes & Yes & Yes & Yes \\
\hline Region specific time trends & No & No & Yes & Yes \\
\hline $\begin{array}{l}\text { Joint significance of year } \\
\text { dummies (F-test) } \\
\text { p-value }\end{array}$ & $\begin{array}{l}0.75 \\
0.47\end{array}$ & & & \\
\hline Observations & 72 & 72 & 72 & 72 \\
\hline
\end{tabular}

Notes:

Standard errors are in parentheses .The dependent variable is the percentage of students choosing a hospitality and catering school as their preferred upper secondary school. In the fourth column robust standard errors are computed

\footnotetext{
*** denotes statistical significance at 1 percent level

** denotes statistical significance at 5 percent level

*denotes statistical significance at 10 percent level
} 